It is proposed that a Native Development and Welfare Council be constituted to take the place of the present Native Development Board; its duty will be to examine, collate, and advise on all schemes. It will act largely through eight standing committees. Two members of the Legislative Council, two representatives of the Missions, and the Director of the Rhodes-Livingstone Institute will be among the twelve members.

On paper this is a magnificent scheme; if carried out it will transform Northern Rhodesia. It may be called a scheme for the establishment of secular mission stations all over the territory. It is not clear from the Memorandum what part is to be played by the Christian Missions which have hitherto borne the burden (latterly with government assistance) of education: how are they to fit in? It is indeed proposed to 'rationalize' teacher training by concentrating into five government normal schools at the Centres the twenty-odd Mission normal schools. 'Certain difficulties have prevented the immediate acceptance of this suggestion, but the question is being further considered.' 'The plan, however, allows for two Mission representatives on the staff of each normal school at the Centres. These, as in regard to the other members of the subordinate staff, are to be temporary and will be replaced by Africans: whether these Africans would be 'Mission representatives' is not stated. Nothing is said about the mission schools which may have been already planted at any of the future $\mathrm{r}, 57^{\circ}$ local centres. The place of religion in education, insisted on by Mr. Scott in this number, is passed over in silence.

\title{
Soil Erosion and Land Use in South Africa
}

The Government of the Union of South Africa wisely called in Dr. Hugh H. Bennett, Chief of the Soil Conservation Service of the United States Department of Agriculture, to advise on the most serious problem confronting them. We use the words 'most serious' deliberately. For should present conditions continue unchecked at the same rate as now South Africa would become a Sahara; and what will then matter social services, colour bars, or anything else? There is plenty of talk about raising the standard of living, of improving nutrition and health, all of which necessary reforms call for more food and better food; but if the land goes out of production-what then? 'There can be no permanence to agriculture anywhere without permanently productive soil, and without a permanent agriculture there cannot be anywhere on earth any assurance whatever of a permanent nation. ... Soil conservation is concerned with the base of human and national welfare.' In these words Dr. Bennett utters a truism which still needs to be hammered home, and not in South Africa only. He did not see the whole of South Africa during his visit of two months, but the principal regions of intensive and semi-intensive farming were covered in some detail. The Transkei, as well as Swaziland and Basutoland, was included in his itinerary. The grim fact that faces the Union is that millions of acres in both European and African areas have been affected (in various degrees of intensity) by erosion: fertility of the soil has thereby been reduced by 25 per cent. and 'probably a few decades more of the careless land-use now unfortunately prevailing will take away so per cent. of the remaining fertility of the country '. In the northern Transvaal it is estimated that more than roo,000 acres of formerly productive land, more or less in a solid block, have lost practically all the original top-soil and are worn down to sub-soil that assumes the hardness of rock during the dry season. The ill-effects of continuing erosion are accumulative. South Africa is drying up on a large scale; and the dessication is due in no small degree to man's action. Dongas and sheetwashing affect springs and wells; streams that formerly ran at lively rates are now dry as a result of destroying vegetation in their headwater areas. Soil swept off by water silts up the dams: ' most of South Africa's reservoirs are filling with sediment.' Erosion and exhaustive cropping have altered the type of vegetation on hundreds of thousands of acres, poisonous plants taking the place of pasture. 
Erosion is a geological process that has gone on for untold millions of years and will still go on; but in so far as erosion is caused by man, it can be halted by man where it has not yet reached the irremediable stage. Farmers accentuate the speed of processes of land decay by burning vegetation and even animal manures, by ploughing up and down slopes, by neglect of rotation of crops. Probably 90 per cent. of the agricultural land of the Union is suffering from such maltreatment. Wherever this state of affairs occurs it is for the State to intervene vigorously and decisively. In Basutoland up-and-down ploughing is now a punishable offence. But legislation is not enough. People must be shown how to treat the land properly. Dr. Bennett, on the basis of his wide experience in U.S.A. (where things were as bad as they are now in South Africa but where energetic remedial measures are in operation), sets out a programme and urges an expeditious and efficient execution thereof.

A passage from the writings of Father Callaway, to be reviewed in our next number, may well be quoted in this connexion: it relates to the Transkei territory.

'How strange it is that sometimes our best blessings turn against us', he writes. 'The first plough to find its way into African use opened out a new era. I should like to find some figures giving the yearly sale of ploughs to Africans since that day more than 100 years ago. It is difficult to-day to find any considerable area of unploughed arable land in these parts. Everywhere the plough has been at work. Everywhere you see patches of red, brown, and black soil. "How splendid", says the progressive friend of the African. Yes, it is splendid. The soil is lending itself to man to provide for his needs. But, like many another friend of man, the soil needs infinite care, and will surely avenge herself if she is not jealously guarded. Man acquires great responsibilities when he marries a wife, and he also acquires great responsibilities when he ploughs open the soil. Mother earth is a jealous spouse. Unfortunately we, in these parts, have been blind to our responsibilities, and the soil has sought refuge from our tyranny in the bed of the ocean. Fierce storms have beaten year by year upon that soil uncovered by the plough, and it has been swept off into torrents and rivers until it reached the sea. We failed to see the writing upon the wall, and fissures in the soil began to abound. Year by year they grew larger and larger, until large areas were useless. The day of small beginnings was indeed fateful. Who would have thought fifty years ago that when the good old wagon, the one universal means of transport, deserted some track which had become a danger to self-respecting wheels and plunged off to find a new way on the veld, it was committing a crime against posterity? It was a rape of the virgin soil and the soil would surely be avenged. The population increased, the livestock increased, but the veld decreased, and the soil was carried away into captivity from which it can never return. Much can still be done, and is now being done by scientific labour, and at heavy cost, to repair the evil, but in many places the day of opportunity has gone and it is too late.' This was written in 1942.

\section{The Union's Reclamation Plans}

Dr. BENNETr's report has confirmed the decision of the Union Government to recast its reclamation plans for the Reserves in a much bolder form and on a much larger scale. It is recognized that the Reserves are congested and in danger of becoming sterile deserts. The Act of 1936 allowed for the acquisition of over 15 million acres of additional land and about one-half of this amount has been added to the Native areas. The Government intend to resume purchase of land as soon as conditions become favourable; but they hold out no promise that it will ever be possible to provide sufficient land to enable every African in the reserves to become a full-time peasant farmer. The best possible use must be made of what land is available. After the Native Economic Commission, 1930-2, drew attention to the deterioration that had set in much was done to reclaim the land until the outbreak of war and consequent shortage of staff and materials checked operations. Now a Twelve Year Plan, 